\title{
Darwin Returns to the Galapagos: Genetic and Morphological Analyses Confirm the Presence of Tramea darwini at the Archipelago (Odonata, Libellulidae)
}

\author{
María Olalla Lorenzo-Carballa ${ }^{1}$, Rosser W. Garrison ${ }^{2}$, Andrea C. Encalada ${ }^{3}$ and Adolfo Cordero-Rivera ${ }^{1, *} \mathbb{D}$ \\ 1 ECOEVO Lab, E.E. Forestal, Campus Universitario A Xunqueira s/n, University of Vigo, \\ 36005 Pontevedra, Spain; malorenzo@uvigo.gal \\ 2 California Department of Food \& Agriculture, 3294 Meadowview Road, Sacramento, CA 95832-1448, USA; \\ argiavivida@gmail.com \\ 3 Laboratorio de Ecología Acuática, Instituto BIOSFERA, Diego de Robles y Vía Interoceánica, Campus \\ Cumbayá, Universidad San Francisco de Quito, 1712841 Quito, Ecuador; aencalada@usfq.edu.ec \\ * Correspondence: adolfo.cordero@uvigo.gal; Tel.: +34-986-801-926
}

check for updates

Citation: Lorenzo-Carballa, M.O.; Garrison, R.W.; Encalada, A.C.;

Cordero-Rivera, A. Darwin Returns to the Galapagos: Genetic and Morphological Analyses Confirm the Presence of Tramea darwini at the Archipelago (Odonata, Libellulidae). Insects 2021, 12, 21. https://doi.org/ $10.3390 /$ insects 12010021

Received: 9 December 2020 Accepted: 28 December 2020 Published: 31 December 2020

Publisher's Note: MDPI stays neutral with regard to jurisdictional clai$\mathrm{ms}$ in published maps and institutional affiliations.

Copyright: (C) 2020 by the authors. Licensee MDPI, Basel, Switzerland. This article is an open access article distributed under the terms and conditions of the Creative Commons Attribution (CC BY) license (https:// creativecommons.org/licenses/by/ $4.0 /)$.
Simple Summary: Flying insects are able to colonize oceanic islands by both active and passive dispersal. Ten species of dragonflies are found in the Galapagos archipelago, located at $900 \mathrm{~km}$ from mainland South America. Shortly after the publication of Darwin's "The Origin of Species", one of the dragonflies from these islands was named after him as Tramea darwini. However, subsequent studies considered it to belong to another continental species of the same genus known as Tramea cophysa. Here, we studied a series of specimens of Tramea collected in 2018 from the Islands of San Cristobal, Isabela, and Santa Cruz, with the aim of determining their specific identity, through a combination of molecular and morphological analyses. Our results indicate that the Galapagos specimens examined belong to Tramea calverti, another continental species, and not to T. cophysa as previously thought. Following the principle of priority in taxonomic nomenclature, Tramea calverti, which was described in 1910 by Muttkowski, should hereafter be considered a synonym of Tramea darwini, which was described in 1889 by Kirby; hence, the species named after Darwin is to be considered valid, inhabiting both the Galapagos islands and continental America.

Abstract: The status of the Tramea species present in the Galapagos Islands (Odonata, Libellulidae) has been the subject of a long-standing debate among odonatologists. Here, we use molecular and morphological data to analyze a series of specimens from this genus collected in 2018 from the Islands of San Cristobal, Isabela, and Santa Cruz, with the aim of determining their relationship with Tramea calverti Muttkowski and with their currently considered senior synonym T. cophysa Hagen. We combined sequencing of mitochondrial and nuclear DNA with morphological examination of several specimens of Tramea, including representatives of continental T. cophysa and T. calverti. Our molecular analyses place the Tramea from Galapagos in the same clade as T. calverti, with T. cophysa as a closely related species. The morphological analyses found only one consistent difference between T. cophysa and T. calverti: the presence of an accessory lobe in the male vesica spermalis of T. cophysa that is absent in T. calverti and in the Tramea from Galapagos. In agreement with our genetic results, the overall morphological differences documented by us indicate that the Galapagos material examined is conspecific with T. calverti. In light of this, and following the principle of priority in taxonomic nomenclature, Tramea calverti Muttkowski, 1910 should hereafter be considered a junior synonym of Tramea darwini Kirby, 1889.

Keywords: dragonflies; taxonomy; islands; molecular markers; morphological analysis; synonymy

\section{Introduction}

Islands are laboratories of evolution in action, mainly due to their isolation and small populations, which drive rapid changes in the biota [1]. For these reasons, 
islands-especially oceanic islands never connected to continents-have attracted the interest of many early naturalists. Already in 1855, de Candolle described the fact that islands have a poorer biota when compared to similar-sized areas of the continents [2], which provided the basis for current theories about island biogeography [3]. In his famous voyage on the Beagle, Darwin visited the Galapagos, where he was impacted by the biota and geology of these islands, which greatly influenced his thoughts about natural selection and evolution [4].

Since the second half of the 19th century, the Galapagos flora and fauna became the subject of more than 20 expeditions, which highlighted the fact that the insect fauna of this archipelago is poor, as expected given its geographical isolation [5]. In the case of the insect order Odonata (dragonflies and damselflies), the diversity is greatly reduced, with only 10 species recorded so far [6-8]. The only odonate species endemic to the Galapagos is Rhionaeschna galapagoensis (Currie), a member of the family Aeshnidae [9]; and the only zygopteran species found in the archipelago is Ischnura hastata (Say) [10]. Seven of the remaining species belong to the family Libellulidae, which includes some species of dragonflies with a wide distribution, like Pantala flavescens (Fabricius), a cosmopolitan species that occurs on all continents (except Antarctica and most of Europe).

Additionally within the Libellulidae, the genus Tramea has been reported for the Galapagos archipelago. This genus is, along with Pantala and some members of the family Aeshnidae, a well-known migrant. The characteristic broad based hindwings present in the species of this genus, allow them to perform long-distance flights at a reduced energetic cost and, in fact, several instances of large swarm migrations have been reported for Tramea species in tropical regions [11]. The genus Tramea is worldwide distributed. In the American continent, Tramea species are found from Canada to Uruguay and central Argentina [12].

Two species of Tramea have been listed for the Galapagos islands: Tramea calverti Muttkowski, 1910 and T. darwini Kirby, 1889 [7,13]. However, the most recent and exhaustive revision of the cophysa group carried out by De Marmels and Rácenis [14], lists only $T$. cophysa from the archipelago, after the authors examined two females of $T$. darwini collected at the islands of Isabela and Floreana.

Ever since its original description based on five females (only one in good condition) deposited in the British Museum, the taxonomic status of Tramea darwini [15] has been discussed by odonatologists. Both Calvert [16] and Ris [17] considered this species a synonym of T. cophysa Hagen, 1867, and this practice has been followed until today [14]. However, and despite a number of past publications dealing with the Tramea species from the Galapagos [16-22] there has been no consensus as to what name should be given to these insular populations. Part of the problem may lie in the lack of a sufficient series of insular material with which to compare with either of the mainland taxa.

Our purpose here is to determine the relationships among the taxa currently going under the names T. calverti, T. cophysa, and T. darwini, based on a sufficient series of specimens from the latter collected on the Galapagos in 2018. To do this, we sequenced nuclear and mitochondrial DNA from representatives of the three taxa and carried out a morphological analysis, comparing individuals of T. darwini from Galapagos with T. cophysa and T. calverti collected at several locations within their continental distribution ranges.

\section{Materials and Methods}

\subsection{Specimen Collection, DNA Extraction, and Sequencing}

A total of 19 specimens of $T$. darwini were collected during a field trip to the Galapagos Islands of Isabela, Santa Cruz, and San Cristobal in August 2018 by AC-R and MOL-C (see Supplementary Table S1 for details on collection locations). Adult individuals were captured with a hand net and placed in $80 \%$ ethanol until DNA extraction. Legs from dried specimens of several Tramea species (T. cophysa, T. calverti, Tramea abdominalis (Rambur, 1842), Tramea basilaris (Palisot de Beauvois, 1817), Tramea binotata (Rambur, 1842), Tramea carolina (Linnaeus, 1763), Tramea lacerata Hagen, 1861 and Tramea virginia (Rambur, 1842)) belonging 
to RWG's personal collection were also used for DNA extraction (see Supplementary Table S1).

Total genomic DNA was extracted from individual legs using the GeneJet DNA extraction kit (ThermoFisher Scientific, Waltham, MA, USA), following the manufacturer's protocol. To reconstruct the phylogenetic relationships between the Tramea species, we amplified fragments of the mitochondrial $16 S$ and Cytochrome Oxidase I (COI) genes, together with the nuclear Internal Transcribed Spacer (ITS), using previously published primers [23-25] (see Supplementary Table S2). PCR reactions were carried out using the DreamTaq Green PCR Master Mix (ThermoFisher Scientific, Waltham, MA, USA). Prior to sequencing, unincorporated primers and dNTPs were removed using Shrimp Alkaline Phosphatase and Exonuclease I (New England Biolabs, Ipswich, MA, USA). Cleaned PCR products were sequenced in both directions using BigDye v.3.1 chemistry (Applied Biosystems, Foster City, CA, USA) in an ABI 3730xl DNA Analyzer (Applied Biosystems, Foster City, CA, USA), by the Macrogen Spain sequencing services.

\subsection{Genetic Analyses}

After sequencing, chromatograms were visually inspected, trimmed and automatically assembled using Geneious v. 9.1.7 (https:/ /www.geneious.com). For some of the ITS sequences, we obtained superimposed traces, characteristic of sequences containing heterozygous insertions/deletions (indels). Allelic sequences were reconstructed using Indelligent v.1.2 [26]. We run BLAST searches for all DNA sequences at the NCBI website (https://blast.ncbi.nlm.nih.gov/Blast.cgi), to ensure that they were not derived from contaminations.

Sequences were aligned using MAFFT $[27,28]$, as implemented in Geneious v 9.1.7. Genetic differentiation between species (p-distance) was estimated for each dataset in MEGA $X$ [29], using the pairwise deletion option, which removes all ambiguous positions for each sequence pair. Mitochondrial DNA (mtDNA) alignments were concatenated for phylogenetic analyses. Phylogenetic relationships among Tramea species were reconstructed using maximum likelihood (ML) and Bayesian inference (BI) approaches. To increase the robustness of the analyses, previously published sequences from several Tramea species downloaded from GenBank (https:/ / www.ncbi.nlm.nih.gov/genbank/) were added to our datasets. Pantala flavescens was selected as the outgroup for the phylogenetic analyses (see Supplementary Table S1).

ML analyses were carried out using RAxML 7.2.8 [30,31] as implemented in Geneious $\mathrm{v}$ 9.1.7., using the rapid bootstrapping and search for best scoring ML tree option, under the GTR + I + G model. Support for the nodes was estimated by running 1000 bootstrap replicates. For BI analyses, we used MrBayes 3.2.6 [32,33], as implemented in Geneious v 9.1.7. BI searches were run for 1.1 million generations, with default priors and with the GTR + I + G substitution model. Resulting phylogenetic trees were edited with TreeGraph 2 [34].

To further confirm the species delimitation within our datasets, we used the single locus distance-based delimitation methods implemented by Automated Barcode Gap Detection (ABGD) [35]. Analyses were run at the ABGD web server (https://bioinfo.mnhn. $\mathrm{fr} / \mathrm{abi} / \mathrm{public} / \mathrm{abgd} / \mathrm{abgdweb} . \mathrm{html}$ ). Fasta files including the aligned ingroup sequences (i.e., the sequences from the Tramea species) for each locus (ITS, COI, and 16S) were used as input files for the analyses, which were carried out with the default options.

\subsection{Morphological Analyses}

We examined ten individuals of Tramea from the Galapagos, to determine if any morphological characters would corroborate the placement of these populations under T. calverti or T. cophysa: two individuals from Isabela island $\left(1 \sigma^{x}, 1\right.$ $)$, six individuals from San Cristobal island ( $30^{7} 0^{7}, 3$ qo $)$ and two from Santa Cruz island $\left(10^{n}, 1\right.$ ㅇ). Our material from Galapagos was compared to 22 individuals of T. cophysa $\left(150^{7} 0^{7}, 7\right.$ 우) from southeastern Brazil and northern Argentina, and 46 individuals of T. calverti (27 $\sigma^{7} \sigma^{7}, 19$ \% 9 ) ranging from Arizona (USA) south to northern Argentina. We also examined specimens of 
both species taken together at Ilha de Marambaia in Rio de Janeiro State, Brazil in order to further determine whether the morphology of the Tramea from Galapagos matched either T. cophysa or T. calverti.

Specimens of T. cophysa and T. calverti belonging to RWG's collection were killed by injecting them with acetone, in order to preserve color patterns and to prevent lateral pressure distortions. Afterwards, they were placed in envelopes and steeped in acetone for $24 \mathrm{~h}$, to promote drying. The Tramea specimens collected at the Galapagos by MOL-C and AC-R, which were preserved in $80 \%$ ethanol, were injected with acetone and steeped in acetone for $24 \mathrm{~h}$, prior to morphological analyses.

Specimens were examined under a Zeiss Discovery V20 Stereo Microscope at magnifications ranging from $7.5 \times$ to $150 \times$. Entire specimens and wings were scanned at $1200 \mathrm{DPI}$ using an Epson Perfection V600 Photo Scanner. Heads and abdomens were photographed using a Leica MC $170 \mathrm{HD}$ digital camera attached to the microscope at varying magnifications and stacked using Helicon Focus software. Vesicas were removed from each male, soaked in hot water, and cleaned with a brush so that the various lobes and details of this structure could be observed. Using a pair of watch forceps, resulting preparations were temporarily pinned with 0.10 minutens and fastened to small lumps of dentist's wax submerged in $95 \%$ ethanol and illustrated via a camera lucida.

The following morphological characters were examined: Head-coloration of vertex, postfrons and labrum in males and females; wings-coloration of wing membrane and extent of Hw basal spot in males and females; vesica spermalis; abdomen-coloration of ventral tergites; and S8 in males and females (abbreviations: $\mathrm{Hw}=$ hind wing; $\mathrm{S}=$ abdominal segment).

\section{Results}

\subsection{Genetic Analyses}

The BLAST searches identified all our obtained sequences as similar to other odonate sequences available in the NCBI database. The final datasets (excluding the outgroup, P. flavescens) consisted of $44 \mathrm{COI}$ and $16 \mathrm{~S}$ sequences and 37 ITS sequences. The $16 \mathrm{~S}$ dataset was $505 \mathrm{bp}$ long, with 39 variable sites and 32 parsimony informative sites; the COI dataset was 451 bp long, with 98 variable sites and 93 parsimony informative sites. The ITS dataset was 894 bp long (including gaps), with 188 variable sites and 85 parsimony informative sites. All the sequences generated in this study have been deposited in the GenBank sequence database (https: / /www.ncbi.nlm.nih.gov/genbank), under accession numbers MW246873-MW246955 (see Supplementary Table S1).

Results of phylogenetic analyses were congruent for both datasets and also for the BI and ML analyses, placing T. darwini in the same clade as the continental T. calverti, while T. cophysa appears as a sister/closely related species. These relationships were supported by high posterior probability and bootstrap values (Figure 1). 

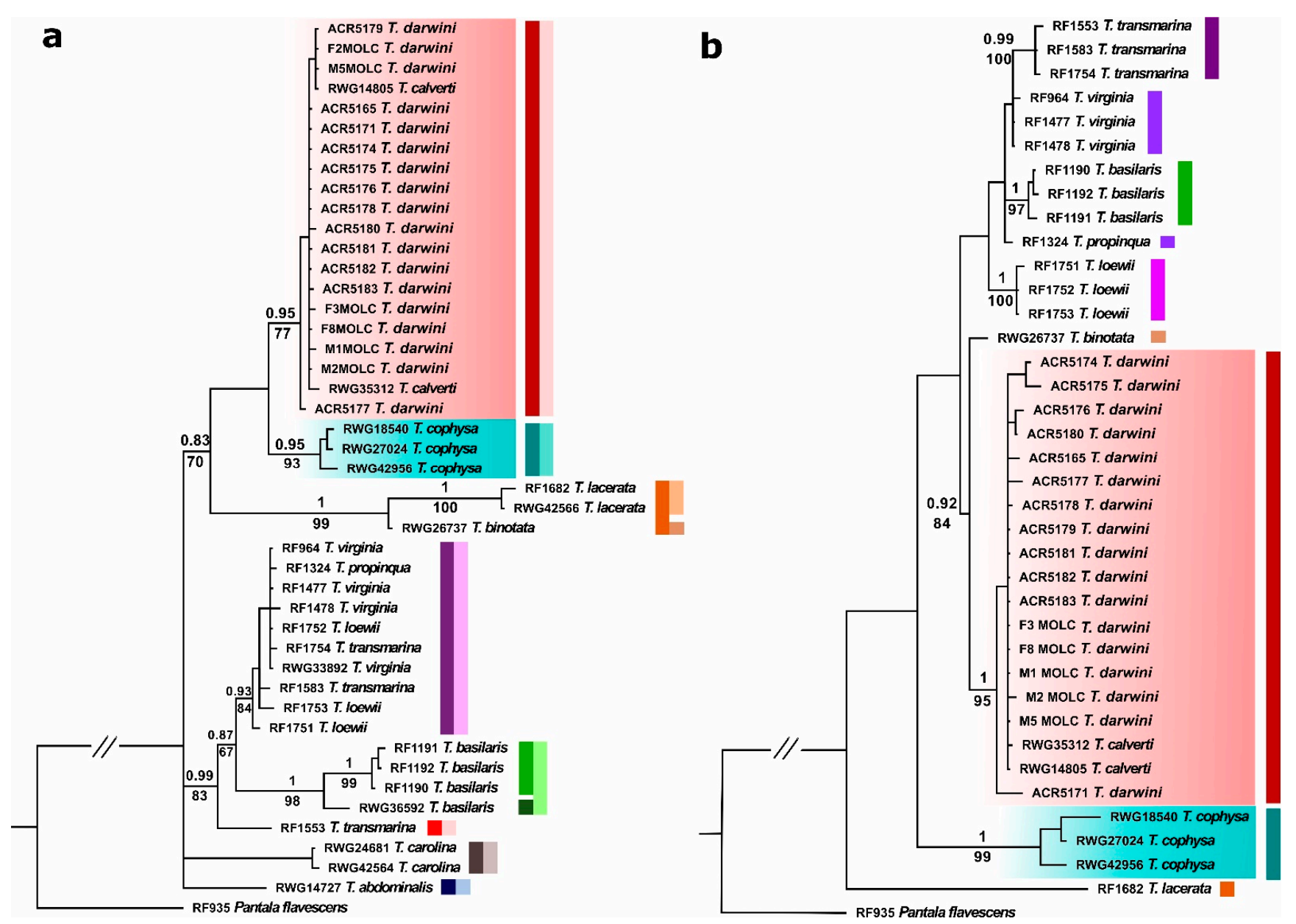

Figure 1. Tree representing the phylogenetic relationships among the Tramea species analyzed in this study, using (a) mtDNA (16S + COI) and (b) nDNA (ITS) data. Numbers above and below branches represent Bayesian posterior probability values and ML bootstrap values, respectively. The clade comprising the Tramea from Galapagos and T. calverti is highlighted in pink, and the T. cophysa clade appears highlighted in blue. The colored bars by each clade represent the proposed species delimitation based on Automated Barcode Gap Detection (ABGD) analyses, where each color represents a delimited species. For the mtDNA markers, the dark and light colour bars represent species delimitations according to COI and $16 \mathrm{~S}$ datasets, respectively.

In agreement with the results of the phylogenetic analyses, the interspecific distances for both the mitochondrial and nuclear datasets group T. darwini with T. calverti. The average distances between $T$. darwini and T. calverti were $0 \%$ for $16 S, 0.4 \%$ for COI and $0.3 \%$ for ITS; while the average distances between T. darwini and T. cophysa were $1.3 \%$ for $16 S$, $3.3 \%$ for COI, and $6.7 \%$ for ITS (see Supplementary Tables S3 and S4).

The ABGD species delimitation analyses identified nine groups (i.e., phylogenetic species) for the mtDNA loci and eight groups for the nDNA locus (see Supplementary Information Data S1). The groups comprised by (i) T. cophysa and (ii) T. darwini and T. calverti were both recovered as different species in all cases (Figure 1).

\subsection{Morphological Analyses}

We found only one morphological difference between T. cophysa and T. calverti. The vesica spermalis of $T$. cophysa in lateral view possesses an accessory lateral lobe (Figure 2c,d), which is absent in T. calverti (Figure 2a). The vesica in specimens of Tramea from the Galapagos also lacks the accessory lateral lobe (Figure 2b). We found no consistent differences in the morphology of the male hamules and cerci nor in female morphologies. 

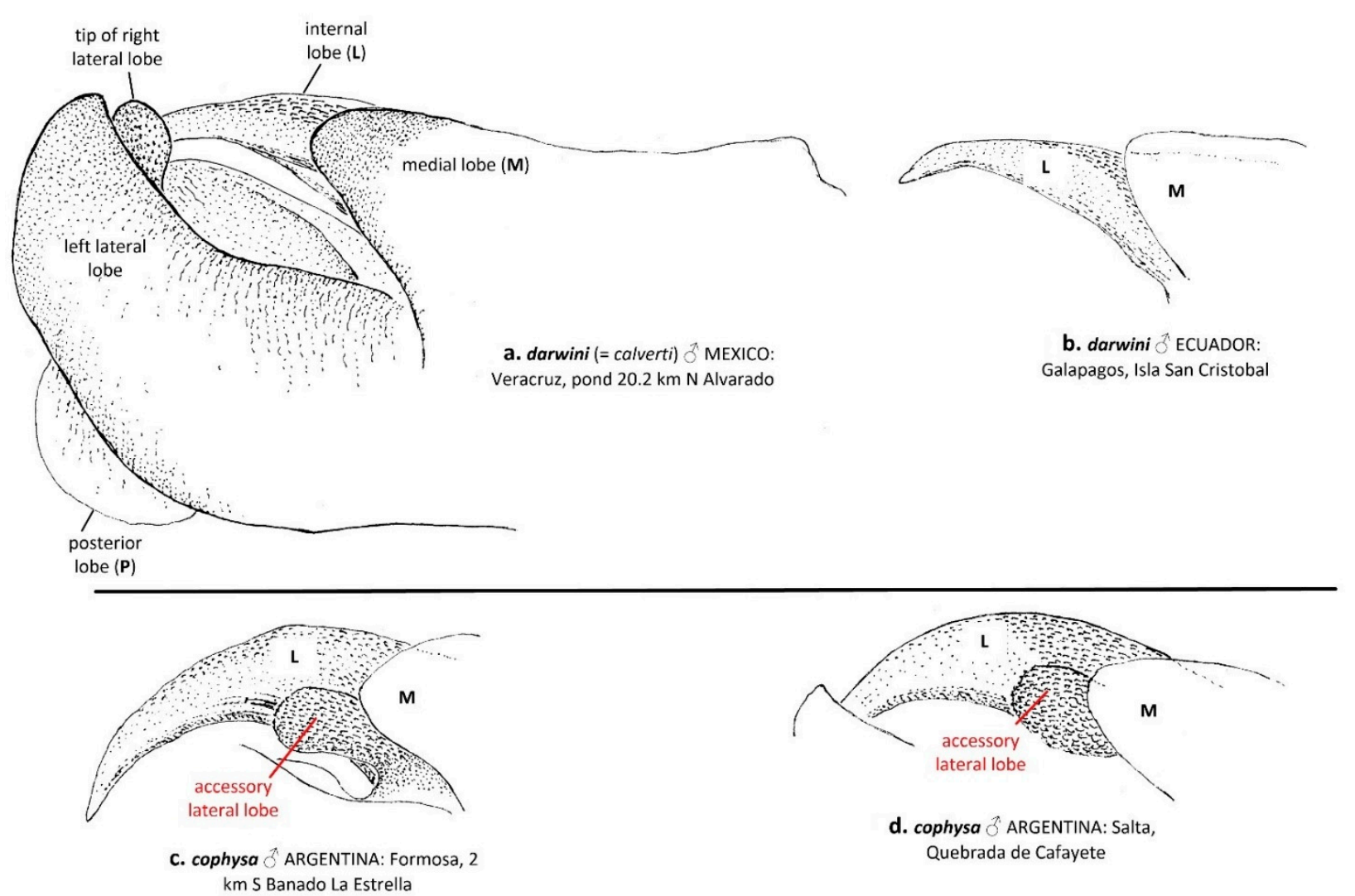

Figure 2. Lateral view of the male vesica spermalis of T. darwini (senior synonym of T. calverti, stat. rev.; a,b) and T. cophysa $(\mathbf{c}, \mathbf{d})$, showing the accessory lateral lobe present in the latter, a characteristic that allows for discrimination between both species. Note that the left lateral lobe, the posterior lobe and the tip of the right lateral lobe appear only illustrated in a.

The vertex, postfrons, and labrum consistently differed in coloration, only in the males, as follows: the dorsal surface of the vertex in T. cophysa is dark metallic violet matching the coloration of the postfrons (Figure $3 a, b$ ). The dorsal surface of the vertex in T. calvert $i$ is pale brown (may be obscured in postmortem preservation) and differs from the dark metallic violet luster of the postfrons (Figure $3 g, h, j$, ). Additionally, the metallic violet luster in T. cophysa extends anteriorly covering the entire postfrons. In T. calverti, the dark metallic violet luster is confined to about the basal half of the postfrons. The labrum is mostly dark brown in males of $T$. cophysa (Figure $3 b$ ) but mostly pale brown in males of $T$. calvert $i$ (Figure 3h,j). Males of Tramea from the Galapagos consistently matched the coloration of T. calverti (Figure 3d,f). We detected no consistent difference in female head coloration between the two species (Figure $3 \mathrm{c}, \mathrm{e}, \mathrm{i}, \mathrm{k}$ ).

The wing membrane in T. cophysa is hyaline in both sexes, and the Hw basal spot is dark brown and can be variable in extent (see Figures 4a-d and 5a,b). The Hw spot in females is often reduced occupying the basal half or less of the length of the Hw base (Figure $4 b$,d and Figure $5 b$ ). In mainland populations of $T$. calvert $i$ the wings are slightly infused with amber (Figure $4 \mathrm{e}-\mathrm{h}, \mathrm{m}, \mathrm{n}$ and Figure $5 \mathrm{~d}, \mathrm{e}$ ) and the $\mathrm{Hw}$ spot is of a slightly lighter brown and is more extensive in both sexes. The size and extent of the Hw patch in mainland populations tends to be uniform exhibiting less variability than in $T$. cophysa (Figure $4 \mathrm{e}-\mathrm{h}, \mathrm{m}, \mathrm{n}$ and Figure $5 \mathrm{~d}$,e). The Galapagos populations exhibit characters of both species, with the Hw patch being variable as in T. cophysa and the wing membrane having less of an infusion of amber coloration compared to mainland populations (Figures $4 \mathrm{i}-1$ and $5 \mathrm{c}, \mathrm{d}$ ). 


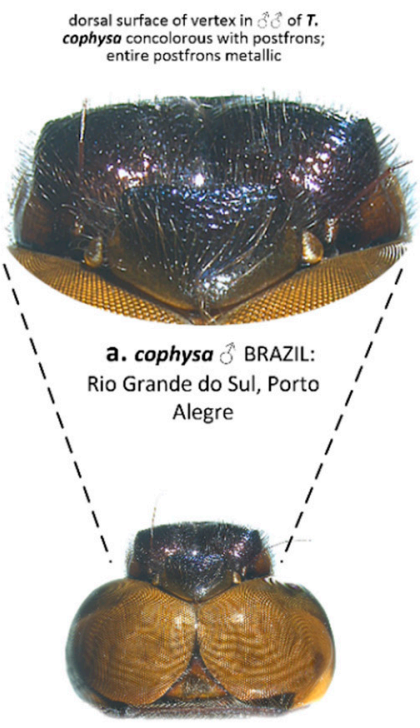

dorsal

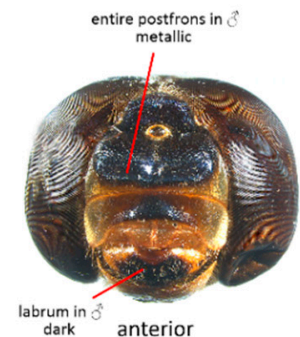

b. cophysa BRAZIL: Rio Grande do Sul, Porto Alegre

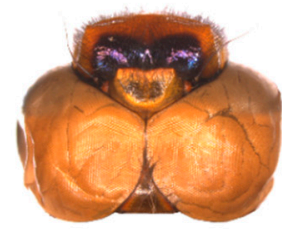

dorsal

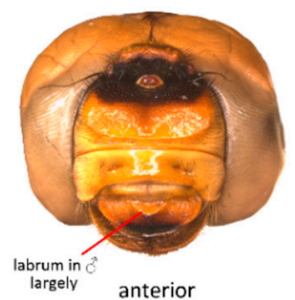

\section{d. darwini}

ECUADOR: Galapagos, Isla San Cristobal

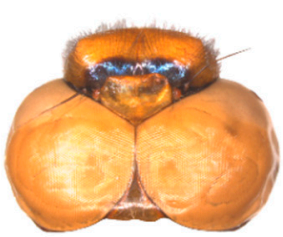

dorsal

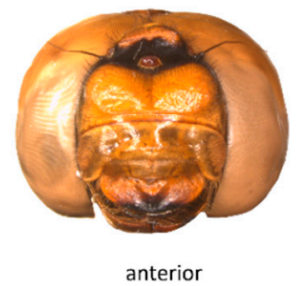

e. darwini? ECUADOR: Galapagos, Isla San Cristobal

dorsal surface of vertex in of $T$. dorwini

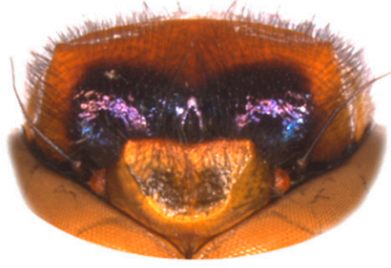

f. darwini 3

ECUADOR: Galapagos,

Isla San Cristobal

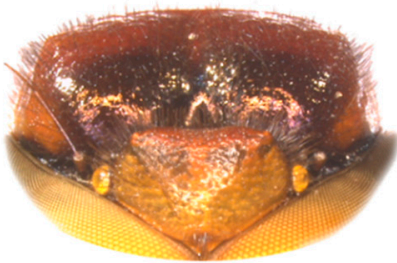

g. darwini (= calverti) 3 USA: Yuma Co., Arizona, Mohawk

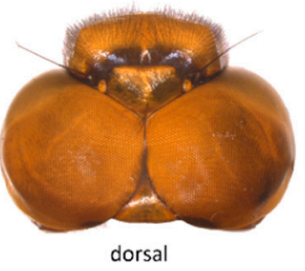

dorsal

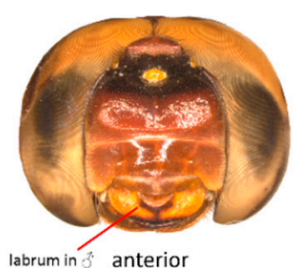

$\underset{\substack{\text { labrum in } \\ \text { pale }}}{3^{+}}$anterior

h. darwini (= calverti)

of USA: Arizona, Mohawk
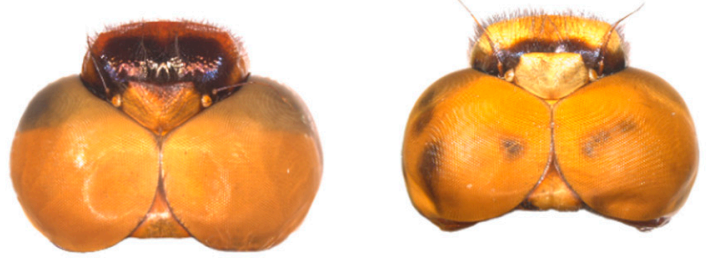

dorsal

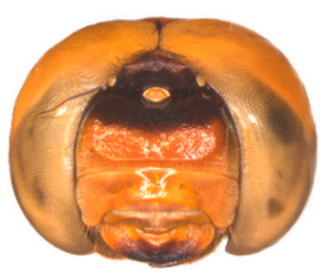

anterior

j. darwini (= calverti) ${ }^{\circ}$ BRAZIL: Rio de Janeiro, Ilha de Marambaia (syntopic w T. cophysa)

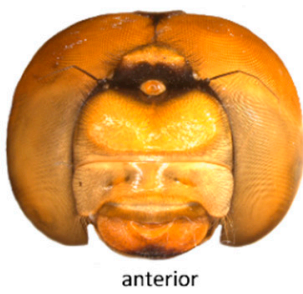

i. darwini $(=$ calverti $)$ Puerto Rico, Laguna Tortuguero

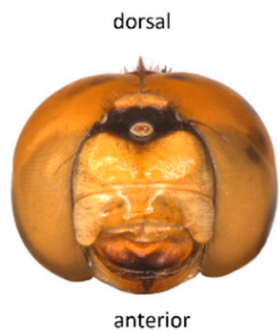

k. darwini (= calverti) 9 BRAZIL: Rio de Janeiro, Ilha de Marambaia (syntopic w T. cophysa)

Figure 3. Dorsal and anterior view of the head of males and females of T. cophysa $(\mathbf{a}-\mathbf{c})$ and T. darwini (senior synonym of T. calverti, stat. rev.) (d-k), showing the differences in coloration of vertex, postfrons and labrum. 

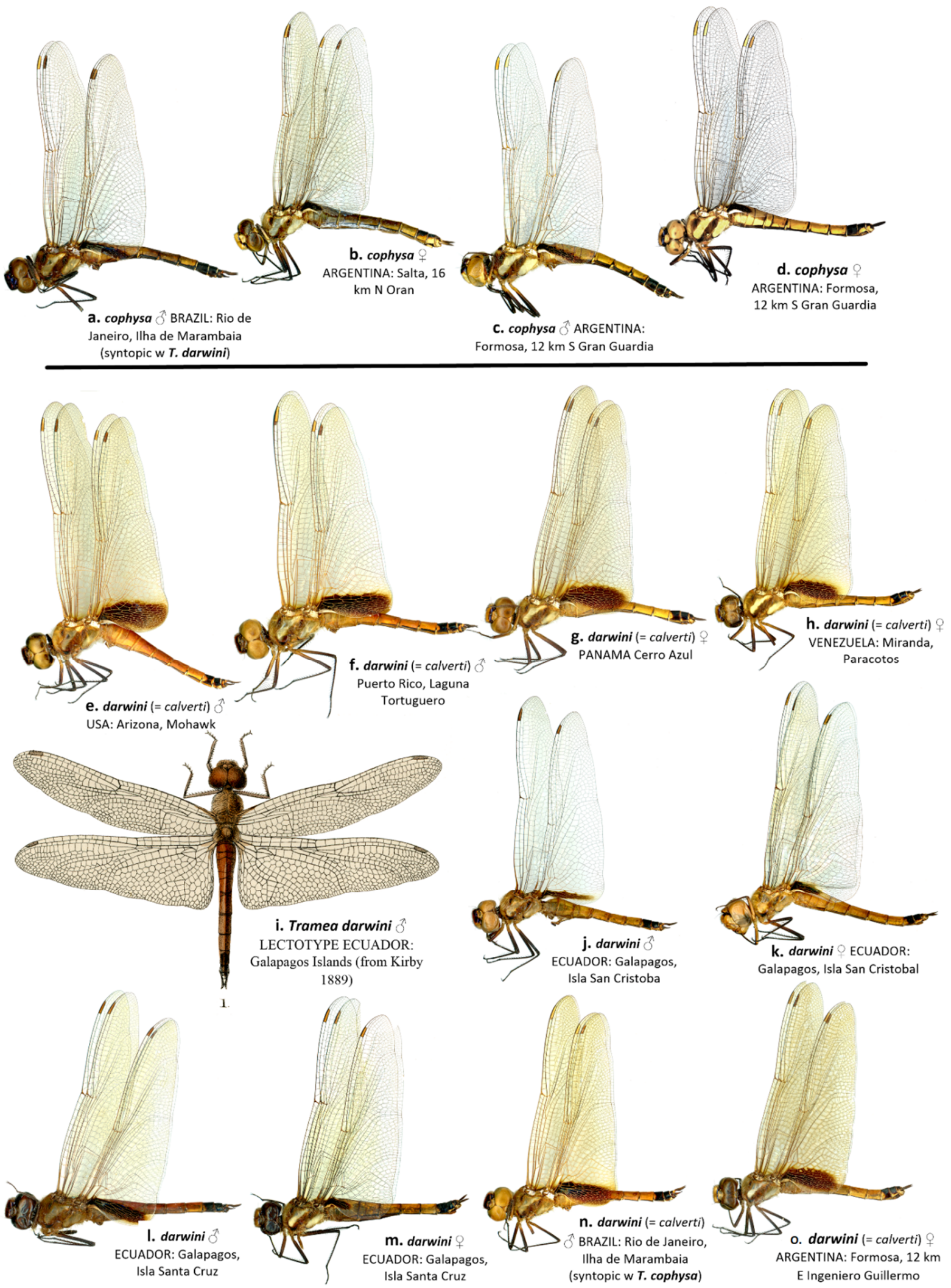

Figure 4. Lateral view of habitus of T. cophysa (a-d) and T. darwini (senior synonym of T. calverti, stat. rev.) (e-o). Dorsal view of the lectotype of T. darwini Kirby 1889 is also included (i). 


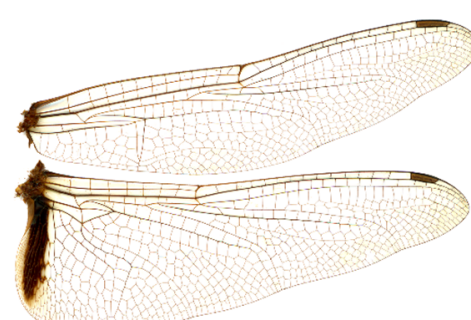

a. cophysa BRAZIL: Rio Grande do Sul, Porto Alegre

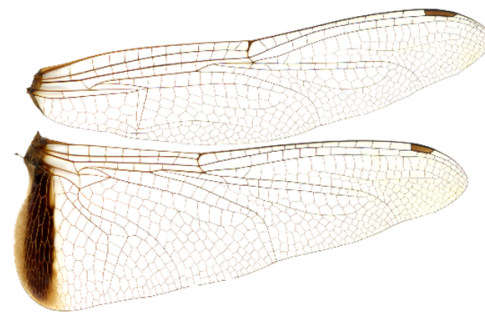

c. darwini ${ }^{2}$ ECUADOR: Galapagos, Isla Isabela

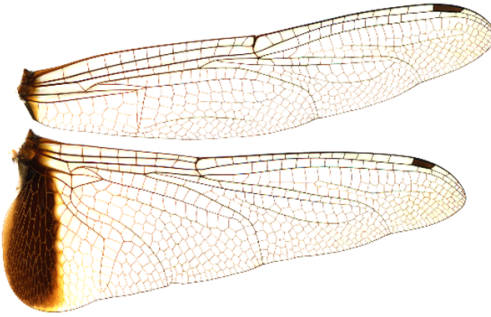

e. darwini $(=$ calverti $)$ FRENCH GUIANA: Kaw Mountain

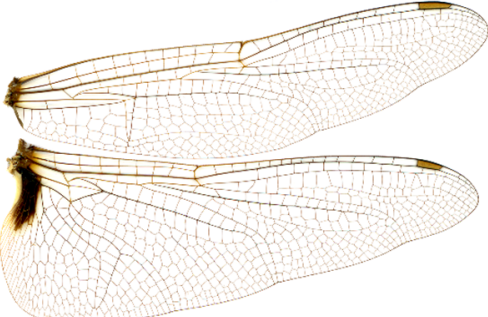

b. cophysa PRGENTINA: Salta, near Parque El Rey

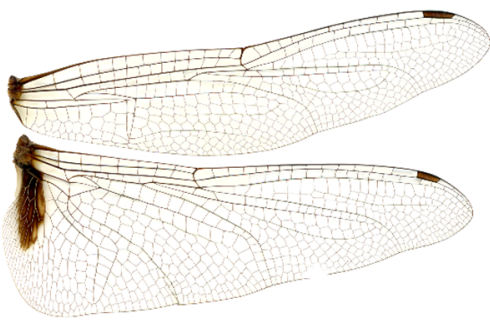

d. darwini Q ECUADOR: Galapagos, Isla San Cristobal

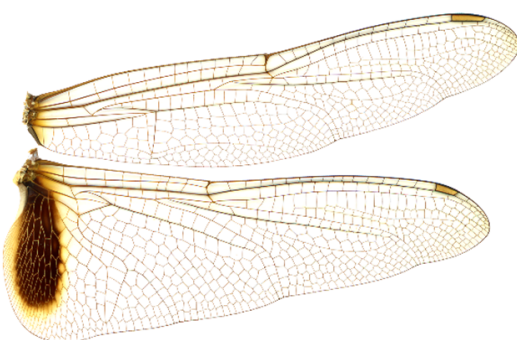

f. darwini (= calverti) \& FRENCH GUIANA: small canal $17 \mathrm{~km} \mathrm{~S}$ Tonate

Figure 5. Wing scans of T. cophysa (a,b) and T. darwini (senior synonym of T. calverti, stat. rev.) (c-f).

Coloration of the ventral abdominal tergites generally differs between T. cophysa and T. calverti. The majority of the ventral tergites in both sexes of $T$. cophysa are dark brown and of the same color as the lateral carinae in most of the abdominal segments (Figure 6a,b). The ventral tergites of some females (Figure $6 \mathrm{c}$ ) may possess a lighter color differing from the dark lateral carinae but in those females, a light dusting of pruinosity is usually present on the more anterior segments (Figure $6 \mathrm{c}$ ). The ventral tergites in T. calverti are always pale brown, with dark markings confined to the vicinity of the lateral carinae (Figure $6 \mathrm{~d}-\mathrm{g}$ ). No pruinosity was observed in any of the T. calverti examined. Abdominal S8 is entirely dark brown in males of T. cophysa (Figure 7a,b), and the same is often observed in the females of this species (Figure 7c); but, in some females S8 shows a pale coloration confined to the lower half of the segment (Figure 7d). Both sexes of $T$. calverti consistently have an inverted pale brown semicircular spot at the base of S8 (Figure 7e,f), which is red or brown in live specimens. Specimens of Tramea from the Galapagos (Figure 7g,h) were consistent in coloration and pattern with $T$. calverti. 


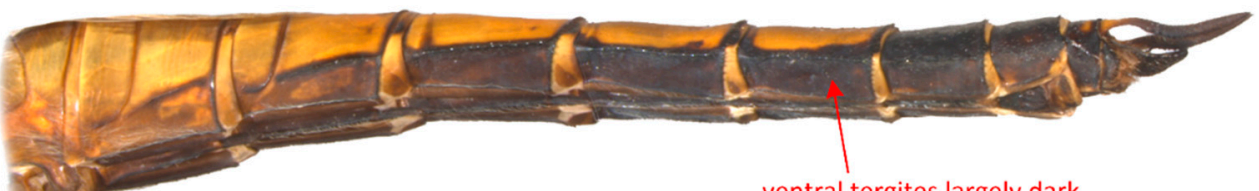

a. cophysa 3 ARGENTINA: Formosa, $12 \mathrm{~km} \mathrm{~S}$ Gran Guardia

ventral tergites largely dark

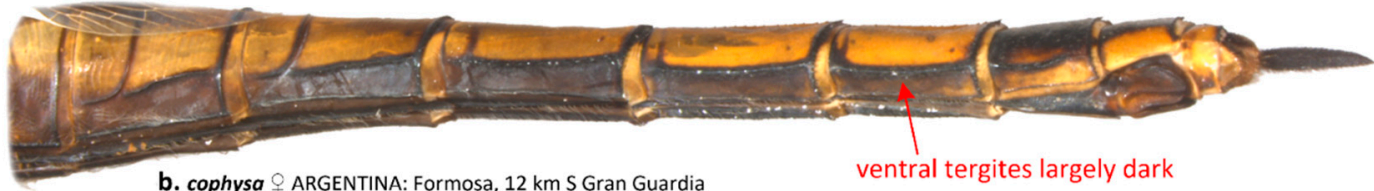

b. cophysa + ARGENTINA: Formosa, 12 km S Gran Guardia

ventral tergites largely dark

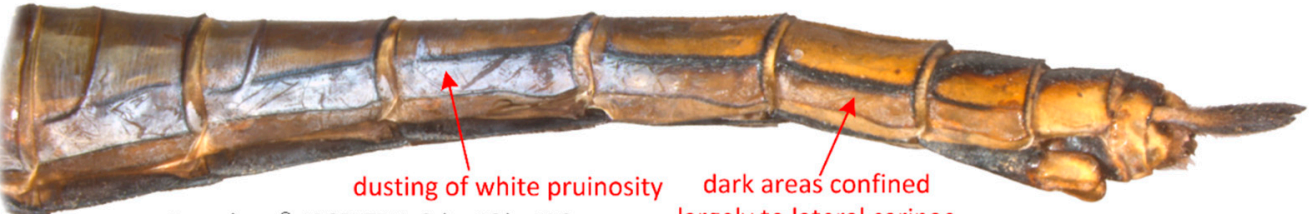

c. cophysa ARGENTINA: Salta, $16 \mathrm{~km} \mathrm{~N}$ Oran largely to lateral carinae
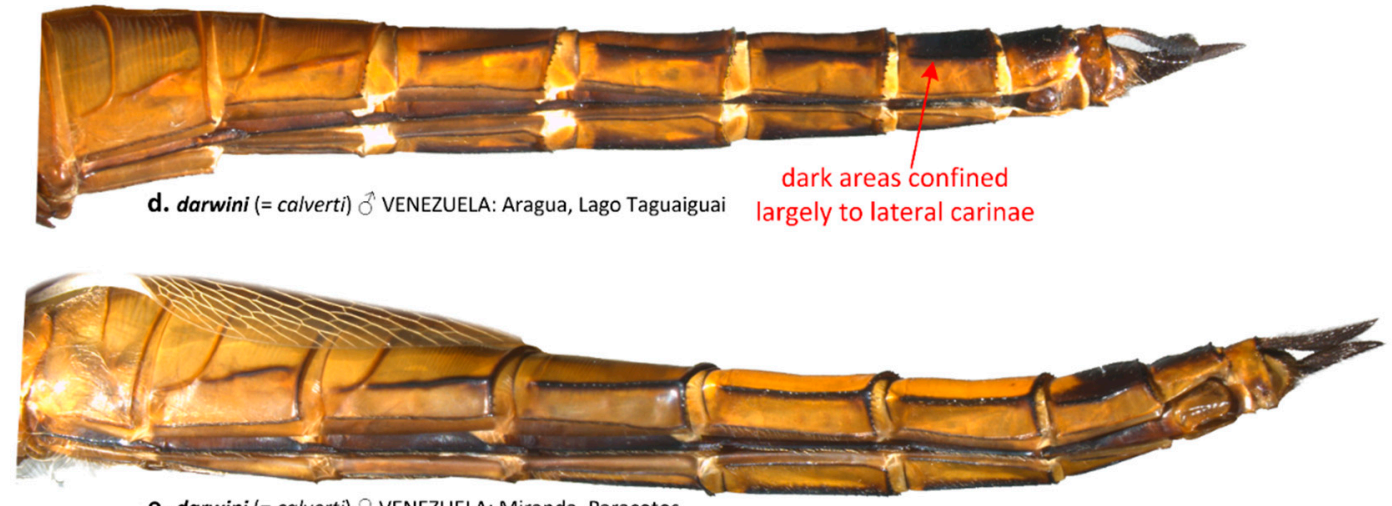

e. darwini (= calverti) \& VENEZUELA: Miranda, Paracotos

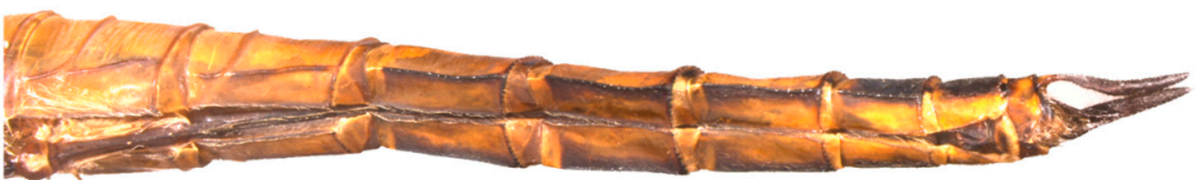

f. darwini ${ }^{2}$ ECUADOR: Galapagos, Isla San Cristobal

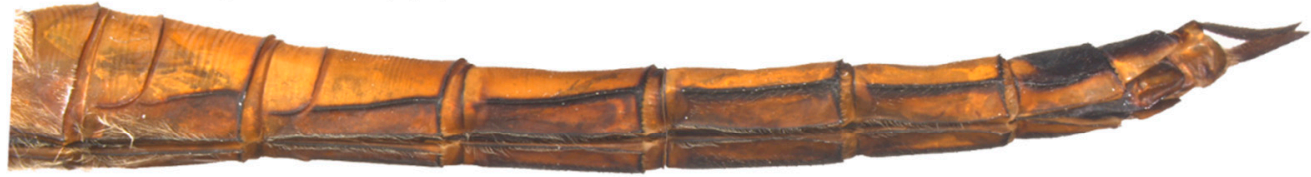

g. darwini $q$ ECUADOR: Galapagos, Isla San Cristobal

Figure 6. Left ventrolateral view of the abdomen of $T$. cophysa (a-c) and $T$. darwini (senior synonym of $T$. calverti, stat. rev.) (d-g). 

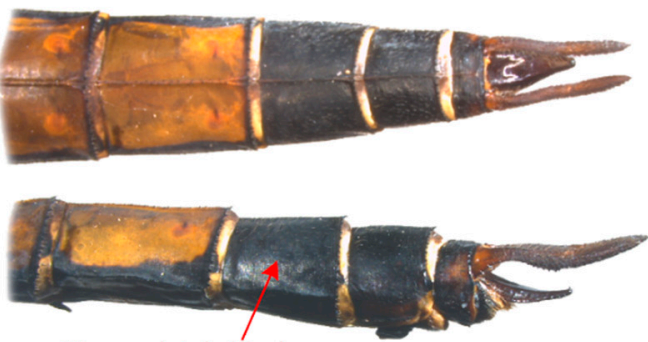

S8 completely black

a. cophysa BRAZIL: Rio de Janeiro, llha de Marambaia (syntopic W T. darwini)

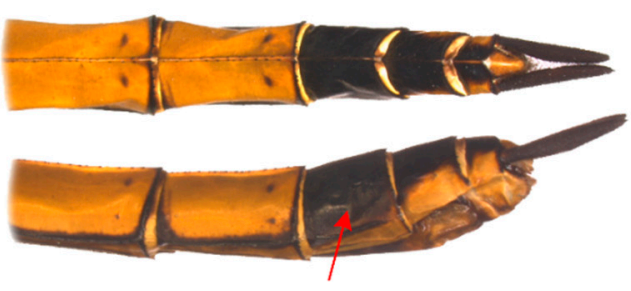

S8 completely black

c. cophysa $q$ ARGENTINA: Formosa, $12 \mathrm{~km} \mathrm{~S}$ Gran Guardia
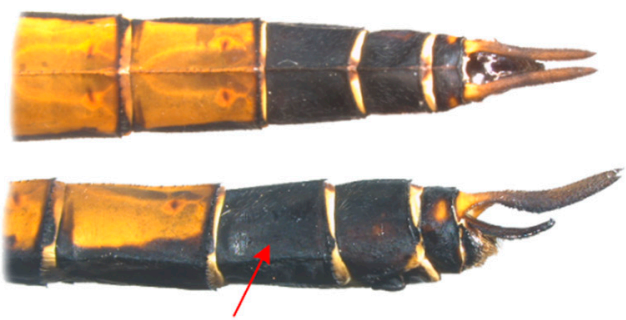

S8 completely black

b. cophysa ARGENTINA: Formosa, 12 km S Gran Guardia
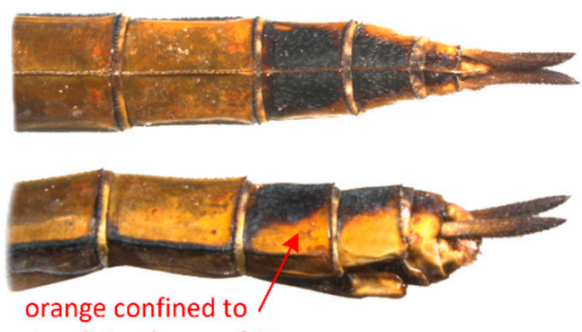

posterolateral area of S8

d. cophysa ARGENTINA: Formosa, 12 km S Gran Guardia
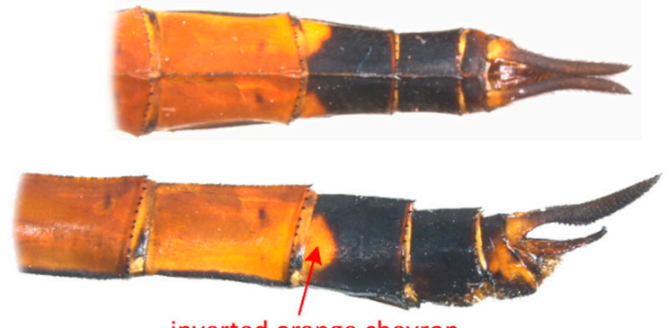

inverted orange chevron confined to base on S8

e. darwini (= calverti) USA: Arizona, ponds by Verde River
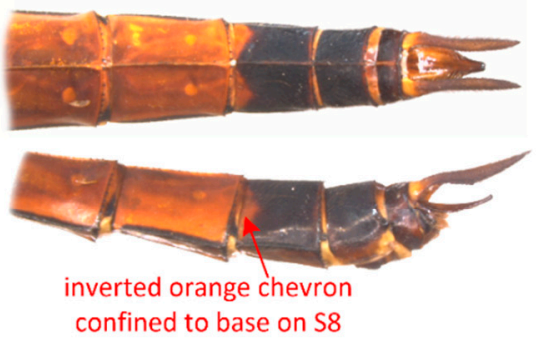

f. darwini (= calverti) 3 BRAZIL: Rio de Janeiro, llha de Marambaia (syntopic w T. cophysa)
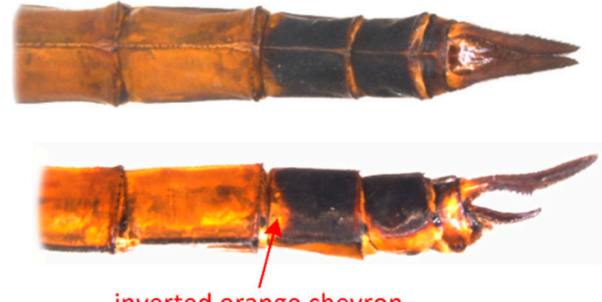

inverted orange chevron

confined to base on S8

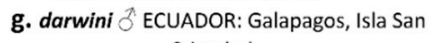
Cristobal
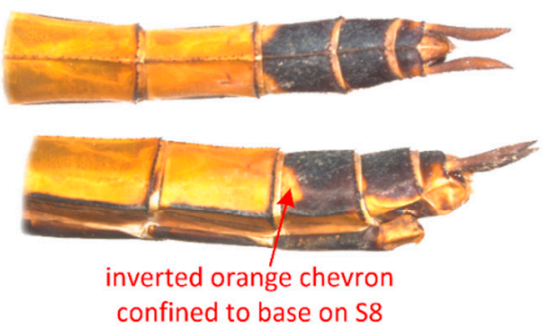

h. darwini (= calverti) + BRAZIL: Rio de Janeiro, llha de Marambaia (syntopic w $T$. cophysa)

Figure 7. Dorsal and lateral views of abdominal segments S7-10 from T. cophysa (a-d) and T. darwini (senior synonym of T. calverti, stat. rev.) (e-h).

\section{Discussion}

The results of our genetic analyses show that the samples of $T$. darwini collected by us at three islands in the Galapagos archipelago (San Cristobal, Isabela, and Santa Cruz), all belong to a clade that also includes the mainland species currently known as 
T. calverti, with T. cophysa as a closely related species. The phylogenetic relationships are concordant between nuclear and mitochondrial DNA and supported by high bootstrap and posterior probability values in both cases. Furthermore, the genetic distances between the Tramea from Galapagos and T. calverti are also lower than the interspecific distances between the Galapagos individuals and T. cophysa (see Results and Supplementary Tables S3 and S4). If we consider the $2 \%$ threshold commonly used as a limit between different species [36], we can conclude that the Tramea from Galapagos belong to T. calverti and not to T. cophysa. ABGD species delimitation methods provided further support for the placement of T. darwini and T. calverti within the same group, separated from T. cophysa.

In agreement with the molecular results, our morphological analyses indicate also a closer relationship between the material collected in the Galapagos islands and mainland T. calverti. This includes also the single morphological character noted above that consistently differentiates both $T$. calverti and T. cophysa: the accessory lobe that occurs in the male sperm vesica of T. cophysa (Figure 2c,d) but is absent in both T. calverti (Figure 2a) and the Tramea from Galapagos (Figure $2 b$ ).

In their exhaustive work on the T. cophysa complex, De Marmels and Rácenis [14] treat $T$. darwini Kirby, 1889, as a junior synonym of the older name, T. cophysa Hagen, 1867; following Calvert [16] (p. 303) who stated: "Tramea darwini based on a female with a much reduced basal wing marking has been shown by Mr. Currie [1901: 386] to vary greatly in this respect. His material is before me and I cannot separate it from some of the examples from Ecuador, while the Haytian female captured by W. Cabot has the basal brown spot of the hind wings reaching no farther backward than $1 \mathrm{~mm}$. beyond the apex of the membranule." De Marmels and Rácenis had access to only two females of T. darwini (Galapagos Is.: Albemarle, 6.VIII.1955; and Charles), a fact that may have accounted for their placement of the Galapagos specimens under T. cophysa.

The original description of T. cophysa states: "Die drei letzten Ringe oben und die vorhergehenden längs der Bauchkante schwarz; unten vom dritten Ringe an schwarz [Body brown, the last three abdominal segments at the top and those entirely along the edge of the abdomen black; at the bottom black from the third abdominal segment.]", a characteristic not present in T. calverti.

A clue to the true identity of the Galapagos material was partially rectified by Peck [13] (pp. 313 and 316) as follows: "[T. cophysa] may have been confused with T. calverti, and its literature records may refer to T. cophysa. De Marmels and Rácenis (1982) clarify the characters and distributions of T. calverti and T. cophysa, and list only T. cophysa from the Galapagos. The key in De Marmels and Rácenis (1982) should be consulted. Dunkle (1989, and pers. comm.) has seen material of T. calverti but not T. cophysa from the Galapagos. My material contains only specimens of $T$. calverti. I have examined Galapagos specimens in USNM and CAS collections and found specimens of T. calverti which had been labelled as T. cophysa. If T. cophysa was actually once present and is now absent in the Galapagos it represents a case of natural extirpation of island populations". Peck's key to Tramea (couplet number 6) also differentiates clearly between both species:

“6a. Underside of abdomen black; abdominal segment 8 all black (Figure 6); hindwing clear with sharply edged dark basal band; male at maturity with frons all violet, male face black

Tramea cophysa

$6 \mathrm{~b}$. Underside of abdomen brown to red; abdominal segment 8 with a semicircular pale basal-lateral spot (Figure 5); hindwing tinged brown with an amberedged basal band; male with only broad band on top of frons violet; female band on frons top narrower, lower frons and face otherwise pale; male at maturity with lower frons and face red Tramea calverti"

Our morphological analyses have shown that the Tramea collected in the Galapagos tally with those of $T$. calverti and not $T$. cophysa; although some differences in wing pattern and coloration between T. calverti and the Galapagos specimens do exist. The female lectotype of $T$. darwini (Figure 4i) possess almost no Hw basal wing spot, which likely led 
Kirby to describe the species as new. Variability in Hw basal wing spot pattern was also illustrated by Asahina [21] and encompasses a greater variability compared to our samples.

Regarding the male vesica spermalis, Gloger [22] stated that he was unable to find any differences in this structure between T. darwini and T. cophysa ("Ich habe die Penis aller mir zur Verfügung stehenden Exemplare des Kontinents (nur sogen. Form c, mit folgender Herkunft: Argentinien: San Isidro, Prov. Buenos Aires; Playadito, Prov. Corrientes; Mascasín, Prov. La Rioja; Bolivien: Roboré) mit denen der Galapagos-Ausbeute verglichen, ohne Differenzen zu finden. [I have compared the penis of all forms of the continent available to me (only so-called form c, with the following origin: Argentina: San Isidro, Prov. Buenos Aires; Playadito, Prov. Corrientes; Mascasín, Prov. La Rioja; Bolivia: Roboré) with those of the Galapagos yield without finding any differences.]"). At first glance, we could not find any differences in the vesica between T. darwini and T. cophysa, until we prepared the structure as described in the Materials and Methods section. Some of the various lobes present in the vesica are difficult to see, and they may be obscured in dried specimens as the ones examined by Gloger [22].

We suggest the following couplet changes in the key provided by De Marmels and Rácenis [14] for separation of T. cophysa from other members of the T. cophysa group, as follows:

"3. Head in male with dorsal surface of vertex deep metallic violet, same color as postfrons, entire postfrons metallic violet (Figure 3a); labrum mostly dark brown (Figure 3b); vesica spermalis with a small accessory lateral lobe (Figure 2c,d); underside of abdomen black in both sexes (some females with pale brown coloration but often dusted with pruinosity basally, Figure 6c), same color as lateral carina (Figure 6a,b); abdominal segment 8 all black (Figure 7a-c); hindwing clear with sharply edged dark basal band. cophysa Hagen

- Head in male with dorsal surface of vertex orange, basal half of postfrons metallic violet (Figure 3); labrum mostly pale brown (Figure 3d,f,h, $\mathrm{j}$ ); vesica spermalis lacking a small accessory lateral lobe (Figure 2a,b); underside of abdomen in both sexes brown to red (Figure $6 \mathrm{~d}-\mathrm{g}$ ); abdominal segment 8 with a semicircular pale brown basal-lateral spot (Figure 7e-h); hindwing tinged brown with an amber-edged basal band.

Given our results, we consider that the Tramea populations present in Galapagos are conspecific with Tramea calverti. Following the principle of priority, this species should be referred to by its older name, T. darwini [15]; from which T. calverti [37] becomes a junior subjective synonym.

All references subsequent to Kirby [15] to Tramea from the Galapagos Islands-Currie [18] (p. 386), Ris [17] (p. 990), Campos [19] (p. 61), Calvert [20] (pp. 228-229), Asahina [21] (p. 2), and Gloger [22] (p. 5) - listed by De Marmels and Rácenis [14] belong, rather than under T. cophysa, under the name T. calverti. The latter applied by Muttkowski as the new name for Tramea longicauda Brauer? var. identified by Calvert [38] (pp. 514-516) based on two males from San José del Cabo, Baja California Sur. De Marmels and Rácenis examined the surviving lectotype from Calvert [20] (p. 606).

Below, we present a new synonymy for Tramea darwini:

Tramea darwini Kirby, 1889 Status Revised

Tramea darwini Kirby [15] (p. 315) (descr. $९$, Galapagos Is., Plate LI., Figure 1, entire + ); -Currie [18] (p. 386) o descr. -Kimmins [39]: 284 (lectotype designation; “The remaining four female syntypes (in bad condition) are still in the B.M. collection. This taxon is currently placed as a synonym of Trapezostigma cophysa (Selys)").

Tramea longicauda Brauer? var.: Calvert [38] (pp. 514-516) (descr. $0^{7} \sigma^{7}$, Baja California, Plate xvii, Figs. 88, 89).

Tramea cophysa?: Calvert [16] (p. 303) (synonymy with T. cophysa).

Tramea calverti Muttkowski [37] (p. 179) (new name for Tramea longicauda Brauer? var.: Calvert, 1895); -Peck [13] (pp. 313, 316) (key, discussion); Dunkle [40] (p. 115) (Galapagos Islands); Gerecke et al. [6] (listed from Galapagos Islands); Peck [7] (p. 121) 
("supposedly from Floreana, Santa Cruz); [the remaining synonymy given by De Marmels and Rácenis [14] (pp. 117, 118) included under this name to follow here] New Synonymy. Tramea cophysa from b Ris [17] (p. 990) (descr.).

Tramea basalis: Carpenter [41] (p. 260) (Barbados); -Campos [19] (p. 61).

Tramea cophysa darwini: Asahina [21] (p. 2), Figure 1 (varibility of Hw); -Linsley \& Usinger [5] (p. 126) (Isabela, Floreana, San Cristóbal, Española) -Turner [42] (pp. 288-289) (discussion variability); -Linsley [43] (p. 9) (Isabela, Floreana, San Cristóbal, Española); Peck [7] (p. 121) (distr., discussion of name for Galapagos populations).

Tramea cophysa: Gloger [22] (p. 5) (discussion variability) -Peck [13] (pp. 313, 316) (key, discussion);

Gerecke et al. [6] (listed from Galapagos Islands but possibly extinct).

Material Examined

Tramea cophysa: BRAZIL, Rio de Janeiro State: $1 \sigma^{7}$, Ilha de Marambaia, Praia da Armaçao (by boat); shallow exposed rain pond, $23.0425^{\circ} \mathrm{S}, 43.9517^{\circ} \mathrm{W}, 4 \mathrm{~m}, 3$ December 2000, Rosser W. Garrison; São Paulo State: $1 \sigma^{\star}$, Sergipe, Propria, ca. $21.1332^{\circ}$ S, $50.8^{\circ} \mathrm{W}, 415 \mathrm{~m}$, August, 1975; Rio Grande do Sul State: $2 \sigma^{\top} \sigma^{\circ}$, Porto Alegre, ca. $30.0346^{\circ} \mathrm{S}, 51.2176^{\circ} \mathrm{W}$, 15 m, Lema; ARGENTINA, Santa Fe Province: 1 , , San Cristobal, ca. $30.3167^{\circ} \mathrm{S}, 61.2333^{\circ} \mathrm{W}$, 67 m), 19 February 1920, J. C. Bradley; Salta Province: $10^{7}$, Quebrada de Cafayate, Hwy 68, $25.9333^{\circ} \mathrm{S}, 65.7214^{\circ} \mathrm{W}, 1500 \mathrm{~m}, 10$ January 1997, Thomas W. Donnelly; $10^{\top}$, Dique El Tunal, pond below dam, $25.2216^{\circ} \mathrm{S}, 64.4753^{\circ} \mathrm{W}, 460 \mathrm{~m}, 27$ January 2012, Natalia von Ellenrieder \& Rosser W. Garrison; 1 ㅇ, Bosques, ca. $34.8352^{\circ}$ S, 58.2207 W, 20 m, April 1980, A. Rodrigues Capítulo; 1 , , Ruta Province: 20 to Parque Nacional El Rey, 8 km from Rta. Prov. 5, pond with pleuston, $25.0167^{\circ} \mathrm{S}, 64.65^{\circ} \mathrm{W}, 790 \mathrm{~m}, 9$ April 1998, Natalia von Ellenrieder; 1 \%, pond at Nat. Rt. 50, $16 \mathrm{~km}$ north to Orán, $23.0082^{\circ} \mathrm{S}, 64.3667^{\circ} \mathrm{W}, 351 \mathrm{~m}, 3$ November 2006, Rosser W. Garrison \& Natalia von Ellenrieder; $1 \sigma^{7}, 1$, Arroyo Yacuy, $15 \mathrm{~km}$ north of Tartagal sobre ruta nacional $34,22.371^{\circ} \mathrm{S}, 63.7725^{\circ} \mathrm{W}, 495 \mathrm{~m}, 6$ November 2006, Rosser W. Garrison \& Natalia von Ellenrieder; Formosa Province: $1 \sigma^{7}$, swamps by route $81,12 \mathrm{~km}$ east of Ingeniero Guillermo N. Juarez, 23.9706 ${ }^{\circ} \mathrm{S}, 61.7039^{\circ} \mathrm{W}, 0$ m, 7 November 2007, Rosser W. Garrison \& Natalia von Ellenrieder; 1 , roadside pool on route 2, $3 \mathrm{~km}$ south of Mojón de Fierro, $26.0492^{\circ} \mathrm{S}, 58.0667^{\circ} \mathrm{W}, 5$ November 2007; $3 \sigma^{7} \sigma^{7}, 1$ q, ponds $12 \mathrm{~km}$ south of Gran Guardia on road 16, 25.965 $\mathrm{S}, 58.9292^{\circ} \mathrm{W}, 6$ November 2007; $20^{\top} \sigma^{\top}$, slough $2 \mathrm{~km}$ $\mathrm{S}$ of Bañado La Estrella, $43 \mathrm{~km}$ north of Las Lomitas on road $28,24.4589^{\circ} \mathrm{S}, 60.3881^{\circ} \mathrm{W}$, 7 November 2007; $10^{7}$, Reserva Natural Formosa, pond, $24.3167^{\circ} \mathrm{S}, 61.7978^{\circ} \mathrm{W}, 60 \mathrm{~m}, 15$ February 2008, Rosser W. Garrison \& Natalia von Ellenrieder; $1 \sigma^{7}$, Bañado La Estrella, $42 \mathrm{~km}$ north of Las Lomitas on road $28,24.4589^{\circ} \mathrm{S}, 60.3881^{\circ} \mathrm{W}, 18$ February 2008 , Rosser W. Garrison \& Natalia von Ellenrieder; 1 ㅇ, ponds $12 \mathrm{~km}$ south of Gran Guardia on road 16, $25.965^{\circ}$ S, $58.9292^{\circ}$ W, 6 November 2007, Rosser W. Garrison \& Natalia von Ellenrieder.

Tramea darwini: U.S.A., Arizona: $1 \sigma^{\prime}$, Maricopa County, slough ponds by Verde River, by Ariz. Hwy. 87, Ft. McDowell Indian Reservation, $33.6758^{\circ} \mathrm{N}, 111.672^{\circ} \mathrm{W}, 1$ September 1976, Rosser W. Garrison; $1 \sigma^{\prime}$, Glendale, cattle pond near Luke elementary School, ca. $33.537^{\circ} \mathrm{N}, 112.34^{\circ} \mathrm{W}, 330$ m, 17 October 1961, Rosser W. Garrison; $10^{\top}$, Yuma County, Mohawk, Gila River at Mohawk Valley Blvd., 32.7144 ${ }^{\circ} \mathrm{N}, 114.014^{\circ} \mathrm{W}, 80 \mathrm{~m}, 30$ September 2002, Rosser W. Garrison \& Natalia von Ellenrieder; PUERTO RICO, Manati Mun.: $1 \sigma^{7}$, Laguna Tortuguero, west end at Hwy 686, 18.4607 ${ }^{\circ} \mathrm{N}, 66.4674^{\circ} \mathrm{W}, 2 \mathrm{~m}, 7$ January 1980, Rosser W. \& Jo Allyn Garrison; same data but: $10^{7}$, 21 June 1981; Vega Baja Mun.: 1 , Laguna Tortuguero, southeast end near Hwy 687, 18.4589 ${ }^{\circ} \mathrm{N}, 66.4239^{\circ} \mathrm{W}, 4 \mathrm{~m}, 7 \mathrm{June} 1981$; Cabo Rojo Mun.: 1 ○ $^{\top}$, Cabo Rojo, ca.18.0771 ${ }^{\circ} \mathrm{N}, 67.1474^{\circ} \mathrm{W}, 30$ m, 6 December 1981, Stgo. Matos; MEXICO, Veracruz State: $10^{7}$, pond $20.2 \mathrm{~km}$ north of Alvarado, by Mex. Hwy. 180, $18.77^{\circ} \mathrm{N}, 95.76^{\circ} \mathrm{W}, 14$ August 1976, Rosser W. \& Jo Allyn Garrison; same data but $10^{\prime}$, Río Coscoapan, $19.4 \mathrm{~km}$ east of Sontecomapan, $18.4892^{\circ} \mathrm{N}, 94.99^{\circ} \mathrm{W}, 13 \mathrm{~m}, 16$ August 1976; BELIZE, Corozal District: 1 ㅇ, Shipstern Reserve, ca. $\left.18.3176^{\circ} \mathrm{N}, 88.1832^{\circ} \mathrm{W}, 11 \mathrm{~m}\right), 24$ October 1992, Tineke Boomsma; VENEZUELA, Aragua State: $20^{\top} \sigma^{\prime}$, Lago Taguaiguai, on Cagua Rd, $10^{\circ} 6^{\prime} 59^{\prime \prime}$ N, $67^{\circ} 27^{\prime} 9^{\prime \prime}$ W, 480 m, Rosser W. \& Jo Allyn Garrison; Miranda State: 1 ㅇ, Parcelamiento Industrial, Paracotos, ca. $10^{\circ} 16^{\prime} 5^{\prime \prime} \mathrm{N}, 66^{\circ} 56^{\prime} 41^{\prime \prime} \mathrm{W}, 600$ m; Bolívar State: 1 
9, Canaima, palm marsh, $6^{\circ} 14^{\prime} 30^{\prime \prime} \mathrm{N}, 62^{\circ} 50^{\prime} 53^{\prime \prime} \mathrm{W}, 700 \mathrm{~m}, 22-25$ September 1980; GUYANA, Potaro-Siparuni Region: 1 \%, Konawaruk watershed, Mango Landing, Essequibo River, $5.315^{\circ} \mathrm{N}, 58.9067^{\circ} \mathrm{W}, 41 \mathrm{~m}, 19$ September 2014, Rosser W. Garrison \& Richard Mohabie; FRENCH GUIANA, 1 \% , Piste de Kaw, about PK 18, ca. $4.6202^{\circ}$ N, 52.2889 ${ }^{\circ}$ W, 250 m, 17 February 1988, Rosser W. Garrison; same data but: $10^{n}, 3$, 9 , small canal $17 \mathrm{~km}$ south of Tonate on route D5, $4.8708^{\circ} \mathrm{N}, 52.5192^{\circ} \mathrm{W}, 18 \mathrm{~m}, 18$ February 1988; same data but: $10^{7}$, Approuague-Kaw, Kaw Mountain, 311 mao; light trap (FRG TRAP XL 2), 4.566 N, 52.2053 W, 325 m, 14 February 2007, N. Jönsson; ECUADOR, Galápagos: $10^{7}, 1$ \&, Galápagos, Isla Santa Cruz, Cerro Mesa; ACR-05182, ACR-05183, 0.6433 S, 90.2876 W, 425 m, 28 February 2014, Adolfo Cordero-Rivera; $20^{7} 0^{7}$, Isla San Cristobal, nearby the Cucuve Eco Hostal, $0.91^{\circ} \mathrm{S}, 89.589^{\circ} \mathrm{W}, 97 \mathrm{~m}, 1$ August 2018, M. Olalla Lorenzo-Carballa; same data but: 2 †क; $10^{\circ}, 1$ \%, Galápagos, Isla Isabela, El Chapin, $0.9452^{\circ} \mathrm{S}, 90.9743^{\circ} \mathrm{W}, 11 \mathrm{~m}, 15$ August 2018;same data but: $1 \mathrm{o}^{\circ}, 1$ \% , Isla San Cristobal, Finca Guadalupe, $0.9266^{\circ} \mathrm{S}, 89.4862^{\circ} \mathrm{W}$, 190 m, 2 August 2018; BRAZIL, Rondônia State: $20^{7} 0^{7}$, Fazenda Rancho Grande, 62 km southwest of Ariquemes, $10.53^{\circ} \mathrm{S}, 62.8^{\circ} \mathrm{W}, 165 \mathrm{~m}, 2-11$ November 1989, Rosser W. Garrison; Rio de Janeiro State: $20^{7} 0^{7}, 1$, Ilha de Marambaia, Praia da Armacao (by boat), 23.0425 S, $43.9517^{\circ}$ W, 4 m, 3 December 2000, Rosser W. Garrison; ARGENTINA, Salta Province: $10^{7}$, Arroyo Yacuy, $15 \mathrm{~km}$ north of Tartagal sobre ruta nacional 34, 22.371 $\mathrm{S}, 63.7725^{\circ} \mathrm{W}, 495 \mathrm{~m}$, 6 November 2006, Rosser W. Garrison \& Natalia von Ellenrieder; Formosa Province: 1 , swamps by route $81,12 \mathrm{~km}$ east of Ingeniero Guillermo N. Juarez, $23.9706^{\circ} \mathrm{S}, 61.7039^{\circ} \mathrm{W}$, 0 m, 7 November 2007, Rosser W. Garrison \& Natalia von Ellenrieder.

\section{Conclusions}

- Our genetic analyses show that the Tramea species from Galapagos belongs to a clade that comprises also the continental species T. calverti, and T. cophysa appears as a closely related species.

- Concordant with the results of the genetic analyses, the morphology of the Tramea collected in Galapagos is closer to T. calverti than to T. cophysa.

- Only one morphological character has been found which consistently discriminates between both species: an accessory lobe in the male sperm vesicle, which appears in T. cophysa, but is absent in both T. calverti and the Tramea from Galapagos.

- Given these results, and following the taxonomic principle of priority, the Tramea species currently found in Galapagos should be referred to by its older name, T. darwini.

Supplementary Materials: The following are available online at https:/ /www.mdpi.com/2075-4 450/12/1/21/s1, Table S1: List of Tramea species included in the present study; Table S2: Primer combinations used to amplify mitochondrial (COI and 16S) and nuclear (ITS) DNA of the Tramea species included in this study; Table S3: Estimates of divergence over sequence pairs between the Tramea species included in this study for the mtDNA datasets; Table S4: Estimates of divergence over sequence pairs between the Tramea species included in this study for the nDNA dataset; Data S1: Results of species delimitation analyses.

Author Contributions: Conceptualization, A.C.-R. and M.O.L.-C.; methodology, M.O.L.-C. and R.W.G.; formal analysis, M.O.L.-C. and R.W.G.; fieldwork, M.O.L.-C. and A.C.-R.; resources, A.C.-R., A.C.E., R.W.G., and M.O.L.-C.; writing-original draft preparation, M.O.L.-C., R.W.G., and A.C.-R.; writing-review and editing, M.O.L.-C., A.C.-R., R.W.G., and A.C.E.; supervision, A.C.-R.; project administration, A.C.-R.; funding acquisition, A.C.-R. and A.C.E. All authors have read and agreed to the published version of the manuscript.

Funding: A.C.E. was supported by USFQ Collaboration grants (Project ID: 15782). A.C.-R. was funded by the Spanish Ministry of Science, including E.R.D. funds (CGL2014-53140-P; PGC2018096656-B-I00).

Institutional Review Board Statement: Not applicable.

Informed Consent Statement: Not applicable. 
Data Availability Statement: DNA sequences obtained from this study are available in the GenBank database, and data are available in the Supplementary Information File. All the Tramea specimens examined and/or used for genetic analyses are deposited in the collections of Adolfo Cordero-Rivera and Rosser W. Garrison.

Acknowledgments: Collection permits were provided by Parque Nacional Galapagos to A.C.E. (Permit No. PC-24-19). The Ecuatorian Ministry of Environment (Ministerio de Ambiente) allowed the genetic analysis of the samples collected in Galapagos (authorization MAE-DNB-CM-2016-0041M-0003). We thank the Galapagos Science Center and the BIOSFERA Institute for their logistic support during the fieldtrips. MOL-C thanks Anais Rivas-Torres and Alfredo Bolaños and his family, for their logistic and personal support during the fieldwork at San Cristobal Island. We are grateful to Andreas Martens, who kindly translated the German text from Gloger to us; as well as to Natalia von Ellenrieder and Jürg De Marmels, who made comments on early versions of the manuscript.

Conflicts of Interest: The authors declare no conflict of interest. The funders had no role in the design of the study; in the collection, analyses, or interpretation of data; in the writing of the manuscript, or in the decision to publish the results.

\section{References}

1. Whittaker, R.J. Island Biogeography. Ecology, Evolution and Conservation; Oxford University Press: Oxford, UK, 1998.

2. de Candolle, A. Géographie Botanique Raisonnée; Ou, Exposition des Faits Principaux et des Lois Concernant la Distribution Géographique des Plantes de L'epoque Actuelle; Masson et cie: Paris, France, 1855.

3. MacArthur, R.H.; Wilson, E.O. The Theory of Island Biogeography; Princeton University Press: Princeton, NJ, USA, 1967.

4. Darwin, C. On the Origin of Species by Means of Natural Selection; John Murray: London, UK, 1859.

5. Linsley, E.G.; Usinger, R.L. Insects of the Galápagos Islands. Proc. California Acad. Sci. 4th Ser. 1966, 33, $113-196$.

6. Gerecke, R.; Peck, S.B.; Pehofer, H.E. The invertebrate fauna of the inland waters of the Galapagos Archipelago (Ecuador)-A limnological and zoogeographical summary. Arch. Hydrobiol. Suppl. 1995, 107, 113-147.

7. Peck, S.B. Smaller Orders of Insects of the Galápagos Islands, Ecuador: Evolution, Ecology, and Diversity; NRC Research Press: Ottawa, ON, Canada, 2001; p. 278.

8. Muddeman, J. A new species for the Galapagos Islands: Great Pondhawk (Erythemis vesiculosa). Argia 2007, 19, 17-18.

9. Cordero-Rivera, A.; Encalada, A.C.; Sánchez-Guillén, R.A.; Santolamazza-Carbone, S.; von Ellenrieder, N. The status of Rhionaeschna galapagoensis (Currie, 1901) with notes on its biology and a description of its ultimate instar larva (Odonata, Aeshnidae). Anim. Biodivers. Conserv. 2016, 39, 45-63. [CrossRef]

10. Lorenzo-Carballa, M.O.; Hassall, C.; Encalada, A.C.; Sanmartín-Villar, I.; Torres-Cambas, Y.; Cordero-Rivera, A. Parthenogenesis did not consistently evolve in insular populations of Ischnura hastata (Odonata, Coenagrionidae). Ecol. Entomol. 2016. [CrossRef]

11. May, M. A critical overview of progress in studies of migration of dragonflies (Odonata: Anisoptera), with emphasis on North America. J. Insect. Conserv. 2013, 17, 1-15. [CrossRef]

12. Garrison, R.W.; von Ellenrieder, N.; Louton, J.A. Dragonfly Genera of the New World: An Illustrated and Annotated Key to the Anisoptera; The John Hopkins University Press: Baltimore, MD, USA, 2006; p. 368.

13. Peck, S.B. The dragonflies and damselflies of the Galapagos Islands, Ecuador (Insecta: Odonata). Psyche 1992, 99, 309-322. [CrossRef]

14. De Marmels, J.; Rácenis, J. An analysis of the cophysa-group of Tramea Hagen, with descriptions of two new species (Anisoptera: Libellulidae). Odonatologica 1982, 11, 109-128.

15. Kirby, W.F. A revision of the subfamily Libellulinae, with descriptions of new genera and species. Trans. Zool. Soc. Lond. 1889, 12, 249-348. [CrossRef]

16. Calvert, P.P. Odonata. In Biologia Centrali Americana: Insecta Neuroptera; R.H. Porter \& Dulau Co.: London, UK, 1906; pp. 213-308.

17. Ris, F. Collections Zoologiques du Baron Edm. de Selys Longchamps. Catal. Syst. Descriptif. Libellulinen 1913, 16, $965-1042$.

18. Currie, R.P. Papers from the Hopkins Stanford Galapagos Expedition, 1898-1899. III. Proc. Wash. Acad. Sci. 1901, 3, 381-389.

19. Campos, R.F. Catálogo Sistemático y Sinonímico de los Odonatos del Ecuador. Rev. Col. Nac. Vicente Rocafuerte 1922, 4, 1-75.

20. Calvert, P.P. Odonata of voyages under the auspices of the New York Zoological Society. Entomol. News 1947, 58, 227-230.

21. Asahina, S. Dragonflies taken by Dr. Sekiguchi in the Galapagos Islands. Publ. Entomol. Lab. Univ. Osaka Prefect. 1961, 6, 1-3.

22. Gloger, H. Bemerkungen über die Odonaten-Fauna der Galapagos-Inseln nach der Ausbeute von Juan Foerster, 1959. Opusc. Zool. 1964, 74, 1-6.

23. Palumbi, S.; Martin, A.; Romano, S.; McMillan, W.O.; Stice, L.; Grabowski, G.R. The Simple Fool's Guide to PCR, 2nd ed.; University of Hawaii Press: Honolulu, HI, USA, 1991; p. 45.

24. Futahashi, R. A revisional study of Japanese dragonflies based on DNA analysis. TOMBO Acta Odonatol. Jpn. 2011, 53, 67-74.

25. Dijkstra, K.D.B.; Kalkman, V.J.; Dow, R.A.; Stokvis, F.R.; Van Tol, J. Redefining the damselfly families: A comprehensive molecular phylogeny of Zygoptera (Odonata). Syst. Entomol. 2014, 39, 68-96. [CrossRef]

26. Dmitriev, D.A.; Rakitov, R.A. Decoding of superimposed traces produced by direct sequencing of heterozygous indels. PLoS Comput. Biol. 2008, 4, e1000113. [CrossRef] 
27. Katoh, K.; Misawa, K.; Kuma, K.; Miyata, T. MAFFT: A novel method for rapid multiple sequence alignment based on fast Fourier transform. Nucleic Acids Res. 2002, 30, 3059-3066. [CrossRef]

28. Katoh, K.; Standley, D.M. MAFFT multiple sequence alignment software version 7: Improvements in performance and usability. Mol. Biol. Evol. 2013, 30, 772-780. [CrossRef]

29. Kumar, S.; Stecher, G.; Li, M.; Knyaz, C.; Tamura, K. MEGA X: Molecular Evolutionary Genetics Analysis across computing platforms. Mol. Biol. Evol. 2018, 35, 1547-1549. [CrossRef]

30. Stamatakis, A. RAxML-VI-HPC: Maximum likelihood-based phylogenetic analyses with thousands of taxa and mixed models. Bioinformatics 2006, 22, 2688-2690. [CrossRef]

31. Stamatakis, A.; Hoover, P.; Rougemont, J. A rapid bootstrapping algorithm for the RAxML web-servers. Syst. Biol. 2008, 57, 758-771. [CrossRef]

32. Huelsenbeck, J.P.; Ronquist, F. MrBayes: Bayesian inference of phylogenetic trees. Bioinformatics 2001, 17, 754-755. [CrossRef]

33. Ronquist, F.; John, P.; Huelsenbeck, J.P. MrBayes 3: Bayesian phylogenetic inference under mixed models. Bioinformatics 2003, 19, 1572-1574. [CrossRef]

34. Stöver, B.C.; Müller, K.F. TreeGraph 2: Combining and visualizing evidence from different phylogenetic analyses. BMC Bioinform. 2010, 11. [CrossRef]

35. Puillandre, N.; Lambert, A.; Brouillet, S.; Achaz, G. ABGD, Automatic Barcode Gap Discovery for primary species delimitation. Mol. Ecol. 2012, 21, 1864-1877. [CrossRef]

36. Hebert, P.D.N.; Ratnasingham, S.; de Waard, J.R. Barcoding animal life: Cytochrome c oxidase subunit 1 divergences among closely related species. Proc. R. Soc. Lond. B 2003, 270, 96-99. [CrossRef]

37. Muttkowski, R.A. Catalogue of the Odonata of North America. Bull. Public Mus. City Milwaukee 1910, 1, 1-207.

38. Calvert, P.P. The Odonata of Baja California, Mexico. Proc. Calif. Acad. Sci. 2nd Ser. 1895, 4, 463-558.

39. Kimmins, D.E. A list of the type-specimens of Libellulidae and Corduliidae (Odonata) in the British Museum (Natural History). Bull. Br. Mus. (Nat. Hist.) Entomol. 1969, 22, 277-305. [CrossRef]

40. Dunkle, S.W. Dragonflies of the Florida Peninsula, Bermuda, and the Bahamas; Scientific Publishers: Gainesville, FL, USA, 1989 ; p. 154.

41. Carpenter, G.H. A contribution towards a list of the dragonflies of Jamaica. J. Inst. Jamaica 1896, 2, 259-263.

42. Turner, P.E., Jr. Odonata of the Galapagos Islands (Odonata). Pan-Pac. Entomol. 1967, 43, 285-291.

43. Linsley, E.G. Insects of the Galápagos (Supplement). Occas. Papers Calif. Acad. Sci. 1977, 125, 1-50. 